ДЗЮБАН Валерий Валерьевич - доктор исторических наук, кандидат педагогических наук, профессор департамента социологии, истории и философии Финансового университета при Правительстве РФ (125993, Россия, г. Москва, ГСП-3, Ленинградский пр-кт, 49; bryanskstudzuban@mail.ru)

\title{
ВЛИЯНИЕ ЛИЧНОСТИ ПЕТРА I НА РЕШЕНИЕ СОЦИАЛЬНЫХ ВОПРОСОВ В РОССИИ
}

\begin{abstract}
Аннотация. Статья посвящена влиянию Петра I на решение социальных вопросов в России. Целью статьи является анализ влияния деятельности Петра I на социальную сферу жизни России в XVIII в. Результаты исследования подтверждают, что, с одной стороны, реформы царя привели к прогрессивным изменениям во всех сферах жизни общества, а с другой - были достигнуты тяжелейшими усилиями русского народа.
\end{abstract}

Ключевые слова: Петр I, царь-реформатор, реформы Петра I, социальные реформы

$\Pi$ ериод правления царя-реформатора Петра I в истории нашей страны является одной из наиболее важных и значимых страниц. Именно при Петре страна пережила те изменения, которые кардинально изменили как ее внутреннюю сущность, так и внешний облик. Именно поэтому петровские преобразования уже не одну сотню лет будоражат умы отечественных и зарубежных историков.

Так, В.М. Живов отмечал, что в ходе Петровских реформ происходило не пустое копирование европейских моделей, а их переосмысление на русской почве [Живов 1996: 90-91]. Э. Зицер называет реформы Петра «преображением» России [Зицер 2008: 21]. В.С. Парсамов писал, что Петр стремился к утилитарности в отношении европейских заимствований в российскую практику [Парсамов 2001: 237]. П.Н. Милюков считал, что многие петровские преобразования оказались ненужным наростом на общей системе российской государственности [Милюков 1905: 83-84]. К.Д. Кавелин считал, что реформы не наступили в России внезапно, а были определены предшествующим временем [Кавелин 1897: 58].

По сей день не угасает интерес к предпосылкам, ходу и итогам петровских преобразований, к урокам, которые наше современное государство может вынести из этого сложного, противоречивого периода, значимость которого, тем не менее, трудно переоценить. Анализ государственной модернизации начала XVIII в. позволяет вынести ценный урок для модернизации, столь актуальной уже в наше время.

Петр I «сочинил из России самую метаморфозис, или претворение» - эти слова П.П. Шафирова, вице-канцлера петровских времен, из его трактата 1717 г. «Рассуждения о причинах Северной войны» дают представление о том, что уже современники отчетливо понимали значение происходящего на их глазах преображения России. Потрясение было особенно сильным потому, что в основе «метаморфозиса» лежала воля одного-единственного человека, подобно античному титану поднявшего непосильную тяжесть. И это несомненно, что бы мы ни говорили о роли его сподвижников, «производительных сил» и т.д. [Анисимов 1989: 7-8].

Грандиозность, всеохватность петровских преобразований такова, что спустя 300 лет и более они не стали только историей, а продолжают быть реальностью, живой жизнью, вошли в повседневный быт людей.

М.П. Погодин, историк, живший в пушкинские времена, писал в своем эссе 
«Петр Великий»: «Мы просыпаемся. Какой ныне день? 1 января 1841 г. - Петр Великий велел считать годы от Рождества Христова, Петр Великий велел считать месяцы от января. Пора одеваться - наше платье сшито по фасону, данному Петром I, мундир по его форме. Сукно выткано на фабрике, которую завел он, шерсть подстрижена с овец, которых развел он. Попадается на глаза книга Петр Великий ввел в употребление этот шрифт и сам вырезал буквы. Вы начинаете читать ее - этот язык при Петре I сделался письменным, литературным, вытеснив прежний церковный. Приносят газеты - Петр Великий их начал. Вам нужно искупить разные вещи - все они, от шелкового шейного платка до сапожной подошвы, будут напоминать вам о Петре Великом... За обедом, от соленых сельдий и картофеля, который указал он сеять, до виноградного вина, им разведенного, все блюда будут говорить вам о Петре Великом. После обеда вы едете в гости - это ассамблея Петра Великого».

Но если бы только шейные платки, соленые сельди да ассамблеи! Погодин продолжает: «Место в системе европейских государств, управление, разделение, судопроизводство, права сословий, Табель о рангах, войско, флот, подати, ревизии, рекрутские наборы, фабрики, заводы, гавани, каналы, дороги, почты, земледелие, лесоводство, скотоводство, рудокопство; садоводство, виноделие, торговля внутренняя и внешняя, одежда, наружность, аптеки, госпитали, лекарства, летоисчисление, язык, печать, типографии, военные училища, академии - суть памятники его неутомимой деятельности и его гения» [Погодин 1846: 341-342].

Но чтобы молодая петровская Россия смогла занять достойное место в системе европейских государств, ей предстоял долгий и тернистый путь познания имеющегося передового опыта ведущих держав, который нужно было не только изучить, перенять, но и приспособить к российской действительности, а далее - и превзойти во многих направлениях своих бывших наставников.

Сама форма первых дипломатических отношений Петра Великого с Западной Европой отвечала еще обычаям прежней Руси и вполне выражала собою условия московского быта; а все подробности посольства, касающиеся участия в нем самого царя и его личной деятельности, указывают лишь на попытку реформатора Руси стряхнуть с себя иго исконной рутины и его пылкие и не всегда удачные стремления в поисках новых форм. Это картина первого непосредственного столкновения двух миров - русского и западноевропейского [Веневитинов 1897: 3-4].

Великое посольство Петра I в Западную Европу в 1697-1698 гг. - каким оно было? О значении этого дипломатического десанта России для международных отношений в Европе конца XVIII в. написано немало. Общепризнанно, что дипломатический результат Великого посольства как типичного азиатского посольского каравана (а таких караванов, прибывших из Персии, Турции, Китая, разъезжало по Европе в XVII-XVIII вв. довольно много), оказался практически нулевым. Ни одна из стран Европы не захотела тогда увязывать свои внешнеполитические планы с Россией и ее намерением воевать с Турцией, но главное значение Великого посольства - все-таки в той особой роли, которое оно играло в жизни Петра I и его страны.

В силу политических обстоятельств начала царствования Петр I был вынужден бороться за свое политическое и физическое существование, жить в мире ненависти и заговоров. Его активной натуре бойца была ближе европейская протестантская модель поведения с доминантой личного успеха, достигаемого трудом, борьбой и знанием. Он высоко ценил всякую технику, терпел религию и был равнодушен к искусству, если не видел в нем хотя бы педагогической пользы. В тогдашнем картезианском мире господствовал механический 
детерминизм - общество, человек и природа казались людям разновидностями машин разного размера, когда в борьбе за существование побеждает тот, кто имеет лучшие машины. А лучшими они были в Голландии и Англии [Гузевич Д.Ю., Гузевич И.Д. 2003: 5-6].

Кораблестроение, точнее, корабли, сыграли особую роль в жизни Петра I. Для него корабль был живым воплощением победы вооруженной знанием человеческой мысли над материалом, природой, вообще над хаотичной стихией. Как церковь в средние века мыслилась кораблем в мире вселенского зла, так и в механических конструкциях конца XVII в. таким кораблем представлялось Петру I государство, создаваемое им как разумным человеком [Анисимов 1989: 39-40].

Поэтому при упоминании о Великом посольстве 1697-1698 гг. речь идет прежде всего о путешествии за профессиональными знаниями, за информацией, в которой остро нуждалась Россия.

Может быть, Петр I впервые в русской истории показал, что знание - это сила, что с помощью знания можно достичь самых трудных политических целей. Поэтому Петр I представляется первым из людей прошлого, который по-своему посмотрел на эту проблему, увидел стратегическое значение информации и взял эту драгоценность в Европе бесплатно или за истинные гроши. Этот дар - видеть в простой на вид глине алюминий - дается не каждому. Он доступен только гению, каким и был Петр I [Гузевич Д.Ю., Гузевич И.Д. 2003: 12].

Также очень важным для судьбы России было путешествие Петра I за границу в 1716 и 1717 гг, отличающееся и продолжительностью, и дальностью поездок по сравнению с 1711 и 1712 гг. Никогда Петр I так долго не находился за границей, как в это путешествие, относящееся к самому блестящему времени его внешней политики. В начале этого путешествия главное внимание обращает на себя свадьба племянницы царя Екатерины Ивановны с герцогом Макленбургским; затем следует пребывание Петра I в разных местах Германии и посещение царем Дании, где он, стоя во главе соединенных флотов различных держав, играл уже главенствующую роль.

Чуть ли не важнейшим результатом этого путешествия было сближение с Францией, с которой до лета 1717 г. отношения были весьма прохладными. Она нужна была и для содействия окончанию войны со Швецией. Громадное значение Франции в течение XVIII в. - ее участие в заключении Ништадского мира, сильное влияние, оказываемое Францией на Россию в эпоху после царствования Петра Великого, а именно во время царствования Елизаветы и Екатерины II, - придают этому посещению им Парижа особенное значение. Число русских туристов, отправившихся в Париж, быстро росло со времени пребывания там самого царя. До тех пор Англия, Голландия и Германия были главной школой для России. Теперь к наставникам присоединилась и Франция. Путешествие Петра I в Западную Европу в 1716 и 1717 гг. было последним в его жизни. Мало того, до нового посещения Западной Европы русским государем (Александр I) прошло почти 100 лет [Брикнер 1880: 567-568].

В 1697-1698 гг. на первом месте у Петра I было учение, теперь же главным стала война и политика. Петр за границей действовал уже как опытный дипломат и великий полководец [Брикнер 1880: 570].

Все эти события, совершавшиеся независимо от воли и желаний Петра, стали как бы фоном начальных лет жизни будущего реформатора России, и они же определили многое из того необычайного, что впоследствии составило его яркую индивидуальность.

По представлениям историков о жизни двора и царской резиденции, Кремль 
XVII в. - это мир церемоний, традиций и условностей, столетних стереотипов поведения - в общем, система, мало способствующая развитию индивидуальности.

В силу сложившихся обстоятельств Петр был нечастым и не очень-то и желанным гостем в Кремле, однако ему все же приходилось появляться там в дни официальных праздников и аудиенций, но это было чуждо для него.

Преображенское, окруженное полями, лесами, с бытом летней царской дачи, способствовало резкому развитию его способностей в силу большой свободы времяпровождения и минимума обязательных занятий с максимумом игр, чаще всего носивших военный характер. Проходили годы, и вместе с ними менялись и игрушки: деревянные солдатики уступали место живым людям, игрушечные баталии на метровом клочке земли переходили в сражения, порой совсем не шуточные. Здесь проявились природные данные Петра: живость восприятия, неугомонность и энергичность, страстность и самозабвенная увлеченность игрой. Это и привело к тому, что «потешные» солдаты и английский бот не остались только игрушками, но стали началом будущих, без преувеличения грандиозных дел.

Также важно то обстоятельство, что рядом с Преображенским располагалась так называемая Немецкая слобода (Кукуй) - поселение иностранцев, приехавших в Россию из разных стран. Этот островок Европы, так не похожий на Москву, на Кремль, где жили бок о бок католики и протестанты, англичане и немцы, притягивал внимание юного Петра. Встречи и знакомства с иноземцами - умными и образованными людьми, такими как Франц Лефорт, Патрик Гордон, многоязычие и непривычные обычаи облегчили Петру преодоление высокого психологического барьера, разделявшего два противоположных мира - православной Руси и «богопротивной» Европы.

Петр приходит к власти летом 1689 г. Это было большей частью следствием хода событий, которые он не направлял.

Бесспорно, абсолютизм России того времени порождал различного рода рассуждения историков о личном вкладе царя в реформы. Большинство авторов дают в основном положительное психологическое описание противоречивой личности Петра. «Почти все эти характеристики возникли на основе априорного предположения, что незаурядная личность Петра наложила отпечаток на всю политическую деятельность правительства и в положительном, и в отрицательном смысле». Некоторые историки склоняются к мысли, что некоторая сумбурность, неусидчивость царя были причиной его недостаточной компетенции и ограниченного участия в преобразованиях. П.Н. Милюков, исследуя реформы в государственно-административной области, отмечает ограниченность сферы влияния Петра: реформы прорабатывались коллективно, и конечные их результаты не всегда осознавались царем в полной мере, да и то опосредованно - через ближайшее окружение. В итоге, Милюков обнаруживает длинный список «реформ без реформатора» [Милюков 1905: 123-124].

Другой же историк Н.П. Павлов-Сильванский делает вывод, что в области реформ Петр был побудительной и движущей силой, часто действовал без учета мнений ближайших советников [Павлов-Сильванский 1897: 200].

«Необходимость движения на новый путь развития была осознана, обязанности при этом определились: народ поднялся и собрался в дорогу; но кого-то ждали; ждали вождя; вождь явился», - это высказывание принадлежит известному историку XIX в. С.М. Соловьеву, который образно описывает ситуацию в стране накануне петровских преобразований.

Страна находилась на пороге великих преобразований, которые должны были свершиться неминуемо, иначе вставал вопрос о дальнейшем существо- 
вании России как таковой. Россия на рубеже веков представляла собой огромнейшую страну с преобладанием аграрной экономики. Расширение границ, выход к морям, столь необходимым для установления успешных дипломатических связей, активное ведение внешней политики с отстаиванием своих национальных интересов были невозможными без укрепления экономики - развития промышленности, увеличения товарности существующих производств, распространения товарно-денежных отношений. Однако, как нам известно, все указанные выше явления не могут происходить в стране, не обеспеченной грамотно выстроенным государственно-административным управлением. Существующая система государственного управления не могла успешно контролировать процессы, развивающиеся в стране. Она уже не отвечала темпу и ходу дел нового времени, морально и физически устарела. Применяющийся в ней подход был неэффективен в ныне существующих условиях.

Однако стоит оценить конкретное положение дел в России накануне петровских преобразований, а не только критиковать его.

Основной отраслью экономики России оставалось сельское хозяйство, где продолжала господствовать трехпольная система земледелия. Главными земледельческими культурами были рожь и овес. Основными орудиями производства оставались соха, борона, серп, коса, медленно вводился плуг. Происходит интенсивное освоение новых посевных территорий на юге России, в Поволжье, Сибири. Наблюдается развитие промыслового хозяйства.

Развивается ремесленное производство. Углубляется разделение труда. В развитии ремесленного производства в конце XVII в. явно прослеживается тенденция превращения его в мелкотоварное производство (увеличивается число ремесленников, работающих на рынок). Развитие мелкотоварного ремесла и рост товарной специализации готовил почву для возникновения мануфактур. Их создание ускорялось государственными потребностями. Мануфактурное производство складывалось в местах развития товарного производства. Если западноевропейская мануфактура действовала на основе вольнонаемного труда, то русская мануфактура основывалась на труде крепостных крестьян, т.к. рынок вольнонаемного труда в России, где господствовало крепостное право, практически отсутствовал.

В конце XVII в. в России интенсивно развивалась торговля. Но на пути развития торговли и купечества имелись существенные препятствия. Остро стоял вопрос о выходе к морям, отсутствие которого тормозило развитие торговли. Иностранный капитал стремился захватить российские рынки, что вело к столкновению интересов с русскими купцами. Купечество России требовало от государства оградить их от конкуренции со стороны иностранных торговцев. В итоге был принят Новоторговый устав (1667), в соответствии с которым иностранным купцам была запрещена розничная торговля на территории России.

Также можно отметить, что во второй половине XVII в. в России развивается тенденция перехода от сословно-представительной монархии к монархии абсолютной. В стране усиливается власть царя (изменение состава Боярской думы в сторону дворянства; победа Алексея Михайловича над патриархом Никоном, стремившимся активно вмешиваться в управление государством; практическое прекращение созывов Земских соборов; отмена местничества, принцип занятия государственной должности в зависимости от знатности рода и служебного положения предков).

Остро стоял вопрос о реформировании вооруженных сил. Сухопутная армия строилась по устаревшим принципам и состояла главным образом из дворянского ополчения. Стрелецкие полки утратили свою боеспособность. Дворяне 
неохотно покидали свои поместья для военных походов, их вооружение и военная выучка отставали от передовых европейских армий. Военная служба была для них обременительной.

Что касается внешней политики, то Россия потерпела поражение в войне с Польшей, также в 1687 и 1689 гг. были предприняты два неудачных похода против Крымского ханства. Поэтому необходимо было реорганизовать армию, построить флот, овладеть побережьем моря, создать отечественную промышленность, перестроить систему управления страной.

Подводя итог Петровским реформам в административной сфере и сфере государственного управления, можно отметить, что их результатом стала невиданная ранее централизация и бюрократизация государственного управления. Новая государственная машина работала гораздо эффективнее, чем старая. «Бюрократия, - пишет по этому поводу Е.В. Анисимов, - необходимый элемент структуры государств нового времени. Однако в условиях российского самодержавия, когда ничем и никем не ограниченная воля монарха - единственный источник права, когда чиновник не ответственен ни перед кем, кроме своего начальника, создание бюрократической машины стало своеобразной “бюрократической революцией”, в ходе которой был запущен вечный двигатель бюрократии. Начиная с петровских времен, он начал работать по присущим ему внутренним законам - ради конечной цели - упрочения своего положения, - мобильно и гибко откликаясь на изменения жизни. Все эти черты созданной петровским режимом бюрократии позволили ей успешно функционировать вне зависимости от того, какой конкретно властитель сидел на троне - умный или глупый, деловой или бездеятельный. Многие из этих черт и принципов сделали сплоченную касту бюрократии неуязвимой и до сего дня» [Анисимов 2009: 430-431].

И вот такую во многом неоднозначную оценку известный историк дает великому преобразователю. «Противоречия, в какие он поставил свое дело, ошибки и колебания, подчас сменявшиеся малообдуманной решимостью, слабость гражданского чувства, бесчеловечные жесткости, от которых он не умел воздерживаться, и рядом с этим беззаветная любовь к отечеству, непоколебимая преданность своему делу, широкий и светлый взгляд на свои задачи, смелые планы, задуманные с творческой чуткостью и проведенные с беспримерной энергией, наконец, успехи, достигнутые неимоверными жертвами народа и великими усилиями преобразователя, - столь разнородные черты трудно укладываются в цельный образ» [Анисимов 2009: 350].

Несколько другой взгляд на государственно-административные преобразования Петра показывает Ханс Баггер. В целом реформы возымели положительный эффект. Их можно рассматривать как явления «относительной прогрессивности» в истории России, поскольку эти преобразования феодального характера способствовали развитию капиталистических отношений. Особым аспектом Баггер называет централизующий эффект реформ, а также развитие производственных сил страны путем создания новых органов управления [Баггер 1985: 75].

\section{Список литературы}

Анисимов Е.В. 1989. Время петровских реформ. Л.: Лениздат. 496 с.

Анисимов Е.В. 2009. Петр Великий: личность и реформы. Москва [и др.]: Питер. 446 с.

Баггер Х. 1985. Реформы Петра Великого. М.: Прогресс. 200 с.

Брикнер А.Г. 1880. Путешествия Петра Великого за границу 1711-1717 гг. Русский Вестник. Т. 150. С. 567-597. 
Веневитинов М.А. 1897. Русские в Голландии (Великое посольство 1697-1698гг.). M. $237 \mathrm{c}$.

Гузевич Д.Ю., Гузевич И.Д. 2003. Великое посольство. СПб: Феникс. 305 с.

Живов В.М. 1996. Язык и культура в России ХVII в. М.: ИД «ЯСК». 624 с.

Зицер Э. 2008. Царство Преображения: Священная пародия и иарская харизма при дворе Петра Великого. М.: Новое литературное обозрение. 238 с.

Кавелин К.Д. 1897. Взгляд на юридический быт древней России. Собрание сочинений: монографии по русской истории. Т. 1. СПб: Типография М.М. Стасюлевича. 1052 с.

Милюков П.Н. 1905. Государственное хозяйство России в первой четверти ХVIII столетия и реформы Петра Великого. СПб: Типография М.М. Стасюлевича. $688 \mathrm{c}$.

Павлов-Сильванский Н.П. 1897. Проекты реформ в записках современников Петра Великого. СПб: Типография В. Киршбаума. 240 с.

Парсамов В.С. 2001. В семиотическом пространстве русско-европейского диалога. - Одиссей: человек в истории. М.: Наука. С. 234-254.

Погодин М.П. 1846. Петр Великий. Историко-критические отрывки. М.: Типография Августа Семена. Т. 1. 464 с.

DZYUBAN Valeriy Valerievich, Dr.Sci. (Hist.), Cand.Sci. (Ped.), Professor of the Department of Sociology, History and Philosophy, Financial University under the Government of the Russian Federation (49 Leningradsky Ave, Moscow, GSP-3, Russia, 125993; bryanskstudzuban@mail.ru)

\section{INFLUENCE OF THE PERSONALITY OF PETER I ON THE SOLUTION OF SOCIAL ISSUES IN RUSSIA}

Abstract. The article is devoted to the influence of Peter I on the solution of social issues in Russia. The purpose of the article is to analyze the activities of Peter I in the social sphere of Russia in the $18^{\text {th }}$ century. The study obtained some results: on the one hand, the reforms of the tsar had led to progressive changes in all spheres of life, and on the other hand, it had been achieved by the hardest efforts of the Russian people.

Keywords: Peter I, tsar-reformer, reforms of Peter I, social reforms 